\title{
MinIREVIEW
}

\section{Mitochondrial DNA Depletion, Oxidative Stress, and Mutation: Mechanisms of Dysfunction from Nucleoside Reverse Transcriptase Inhibitors}

\author{
William Lewis, William C. Copeland, and Brian J. Day \\ Department of Pathology (WL), Emory University, Atlanta, Georgia; Laboratory of Molecular Genetics (WCC), \\ National Institute of Environmental Health Sciences, Research Triangle Park, North Carolina; and Department of \\ Medicine (BJD), National Jewish Medical Research Center, Denver, Colorado
}

\section{Mitochondrial Dysfunction Hypothesis}

Clinical, pharmacological, cell, and molecular biological evidence links altered mitochondrial (mt) DNA replication to the toxicity of nucleoside reverse transcriptase inhibitors (NRTI) (Brinkman et al, 1999; Carr et al, 1999; Kakuda, 2000; Moyle, 2000; Swartz, 1995). Damage in various tissue targets results in organspecific pathological changes or systemic effects that include elevated plasma lactate. Elevated plasma lactate now is seen commonly with combined antiretroviral therapy (HAART) (Carr et al, 1999; Moyle, 2000). Mitochondrial toxicity of NRTIs was established by previous investigations (Brinkman et al, 1998; Kakuda et al, 1999; Lewis, 1998; Lewis et al, 1991, 1992; Lewis and Dalakas, 1995; Swartz, 1995), but the clinical impact of NRTI toxicity in patients with AIDS remains controversial. Long-term side effects of NRTIs may be more common because of increased AIDS survival. Heightened clinical awareness raises the index of suspicion. In turn, this may impact on increased prevalence. Table 1 summarizes evidence for the toxicity of various NRTIs. Mechanistic analysis is included below.

Three interrelated mechanisms may be operative in NRTI toxicity (Fig. 1). The first was observed clinically and experimentally. Its principal feature was energy deprivation secondary to mtDNA depletion. Concomitant with or resulting from mitochondrial energy deprivation is the second key event: mitochondrial oxidative stress. Evidence for this stems from in vivo

Received December 20, 2000.

This work was supported by Grants RO1 HL59798 and HL65167 to WL and R01 HL59602 to BJD.

Address reprint requests to:

Dr. William Lewis, Department of Pathology, Emory University, 1639 Pierce Drive, Room 7117, Atlanta, Georgia 30322. E-mail: wlewis@emory.edu studies with NRTIs and from correlative data in other systems. Lastly, mtDNA mutations may result from oxidative mtDNA damage, aberrant mtDNA replication, and altered mtRNA transcription. Together, these form the "mitochondrial dysfunction hypothesis." This hypothesis takes into account all of the pathophysiological events that are important in NRTI toxicity. In some ways, it is analogous to approaches that examine defects in genetic mitochondrial illnesses in which the defective mitochondrial gene product, oxidative stress, and the environment contribute to disease pathogenesis (Schapira and Cooper, 1992).

\section{mtDNA, DNA Polymerase- $\gamma$, and NRTI Toxicity}

Nuclear DNA encodes $80 \%$ of the oxidative phosphorylation genes (OXPHOS, the principal source of myocardial energy), but 13 OXPHOS gene products are encoded by mtDNA (reviewed in Wallace, 1992a). Although mitochondrial genetic diseases result from point mutations or deletions of mtDNA, acquired defects in mtDNA replication resulting from NRTI's inhibition of mtDNA replication may yield phenotypic OXPHOS defects that mimic the genetic illnesses.

DNA polymerase- $\gamma$ (DNA pol- $\gamma$ ) is the mtDNA replication enzyme in eukaryotic cells. Substantial homology exists among DNA pol- $\gamma$ extracted from fly, frog, and human. DNA pol- $\gamma$ is an enzyme encoded by the nuclear genome that contains two subunits, a large 125 to $140 \mathrm{kDa}$ subunit containing catalytic activity for polymerase and exonuclease and a smaller accessory subunit of 41 to $55 \mathrm{kDa}$ required for processive synthesis (Carrodeguas et al, 1999; Gray and Wong, 1992; Insdorf and Bogenhagen, 1989; Lim et al, 1999; Wang et al, 1997; Wernette and Kaguni, 1986). The accessory subunit provides tighter DNA binding of the complex, thus allowing highly processive DNA synthesis (Lim et al, 1999). 
Table 1. Mitochondrial Toxicity of NRTIs

\begin{tabular}{llcc}
\hline NRTI Anatomic or Tissue Target & Clinical Evidence for Mitochondrial Toxicity & Experimental Evidence for Mitochondrial \\
Toxicity
\end{tabular}

AZT Skeletal muscle and heart muscle. Mitochondrial myopathy including ragged red fibers; Decreased mtDNA in vitro. Decreased mtDNA, Lactic acidosis with anaerobic metabolism in many tissues decreased muscle mtDNA, paracrystals; phosphocrea depletion in exercised patients. Cardiomyopathy with cardiac dilatation and failure; mitochondrial cristae mtRNA, mitochondrial polypeptides, and including liver. dissolution. Markedly elevated serum lactate; Reye's mitochondrial ultrastructural damage in vivo. syndrome-like findings. Hepatomegaly with fatty change (steatosis). Pediatric AIDS patients are relatively resistant.

Dalakas et al, 1990

Arnaudo et al, 1991

Chattha et al, 1993

d'Amati et al, 1992

Freiman et al, 1993

Herskowitz et al, 1992

Jolliet and Widmann, 1990

Kohler and Lewis, 1995

Lewis, 1998

Lewis and Dalakas, 1995

Lewis et al, 2000

Lipshultz et al, 2000

Sinnwell et al, 1995

Low $\mathrm{K}_{\mathrm{i}}$ for AZTTP with mammalian DNA pol- $\gamma$. Failure of exonulcleolytic excision of terminally

incorporated AZT. Mixed (competitive and noncompetitive) $K_{i}$ with cardiac DNA pol- $\gamma$ against various templates.

Benbrik et al, 1997

Cherrington et al, 1995

Corcuera et al, 1996

Corcuera Pindado et al, 1994

Eriksson et al, 1995

Hobbs et al, 1995

Martin et al, 1994

Nusbaum and Joseph, 1996

Semino-Mora et al, 1994

Schroder et al, 1996

Wang et al, 1996

Oxidative stress

de la Asuncion et al, 1998

Gerschenson et al, 2000

Szabados et al, 1999

AZT inhibits adenylate kinase:

Barile et al, 1994

AZT inhibits Adenine nucleoside translocator: Barile et al, 1997

AZT inhibits NADH-cytochrome c reductase:

Modica-Napolitano, 1993

AZT inhibits mitochondrial permeability

transition:

Elimadi et al, 1997

AZT inhibits NADH oxidase

Pereira et al, 1998

AZT treatment has no effect on mitochondria Herzberg et al, 1992

Painful peripheral neuropathy in $50-100 \%$ of patients Berger et al, 1993

Dubinsky et al, 1989

Merigan et al, 1989

Yarchoan et al, 1990

Inhibition of mtDNA replication in MOLT cells. Mitochondrial structural changes and lipid accumulation in nerves of DDC-treated rabbits. Anderson et al, 1992, 1994

Chen and Cheng, 1992

Chen and Cheng, 1989

Chen et al, 1991

Cherrington et al, 1995

Eriksson et al, 1995

Feldman et al, 1992

Feldman and Anderson, 1994

Keilbaugh et al, 1993

Kukhanova et al, 1995

Martin et al, 1994

Starnes and Cheng, 1987

Tsai et al, 1994

3TC

Kinetics with HeLa DNA pol- $\gamma$

Hart et al, 1992

Martin et al, 1994

Carbovir

$\mathrm{K}_{\mathrm{m}}$ with gapped duplex DNA

Parker et al, 1991

White et al, 1989 
Table 1. Continued

\begin{tabular}{|c|c|c|c|}
\hline NRTI & Anatomic or Tissue Target & Clinical Evidence for Mitochondrial Toxicity & $\begin{array}{c}\text { Experimental Evidence for Mitochondrial } \\
\text { Toxicity }\end{array}$ \\
\hline DDI & Peripheral nerve & $\begin{array}{l}\text { Painful peripheral neuropathy in 3-22\% of patients } \\
\text { Cooley et al, } 1990 \\
\text { Lambert et al, } 1990\end{array}$ & $\begin{array}{l}\text { Distorted cristae and decreased mtDNA in } \\
\text { CEM cells } \\
\text { Cui et al, } 1997 \\
\text { Martin et al, } 1994 \\
\text { Medina et al, } 1994 \\
\text { Youssef and Badr, } 1992\end{array}$ \\
\hline D4T & Peripheral nerve & $\begin{array}{l}\text { Painful peripheral neuropathy in } 55 \% \text { of patients } \\
\text { Browne et al, } 1993 \\
\text { Cohen et al, } 1994\end{array}$ & $\begin{array}{l}\text { Distorted cristae and decreased mtDNA in } \\
\text { CEM cells } \\
\text { Cui et al, } 1997 \\
\text { Martin et al, } 1994 \\
\text { Medina et al, } 1994\end{array}$ \\
\hline FIAU & $\begin{array}{l}\text { Liver, skeletal, and cardiac muscle, } \\
\text { peripheral nerve }\end{array}$ & $\begin{array}{l}\text { Lactic acidosis; hepatic failure and steatosis; renal } \\
\text { failure; skeletal and cardiac myopathy; peripheral } \\
\text { neuropathy } \\
\quad \text { Stevenson et al, } 1995\end{array}$ & $\begin{array}{l}\text { FIAU incorporation into mtDNA in vivo and in } \\
\text { vitro. Mitochondrial structural defects and } \\
\text { intracellular fat accumulation in vitro and in } \\
\text { vivo. Competitive } \mathrm{K}_{\mathrm{i}} \text { of FIAUTP, FMAUTP with } \\
\text { DNA pol- } \gamma(0.02 \mu \mathrm{M}) \text {. } \\
\text { Cui et al, } 1995 \\
\text { Klecker et al, 1994 } \\
\text { Lewis et al, 1994a, 1996, } 1997 \\
\text { Lewis and Tankersley, 1995 } \\
\text { Richardson et al, } 1994 \\
\text { Tennant et al, } 1998\end{array}$ \\
\hline
\end{tabular}

NRTIs, nucleoside reverse transcriptase inhibitors; AZT, zidovudine; DDC, zalcitabine; 3TC, lamivudine; DDI, didanosine; D4T, stavudine.

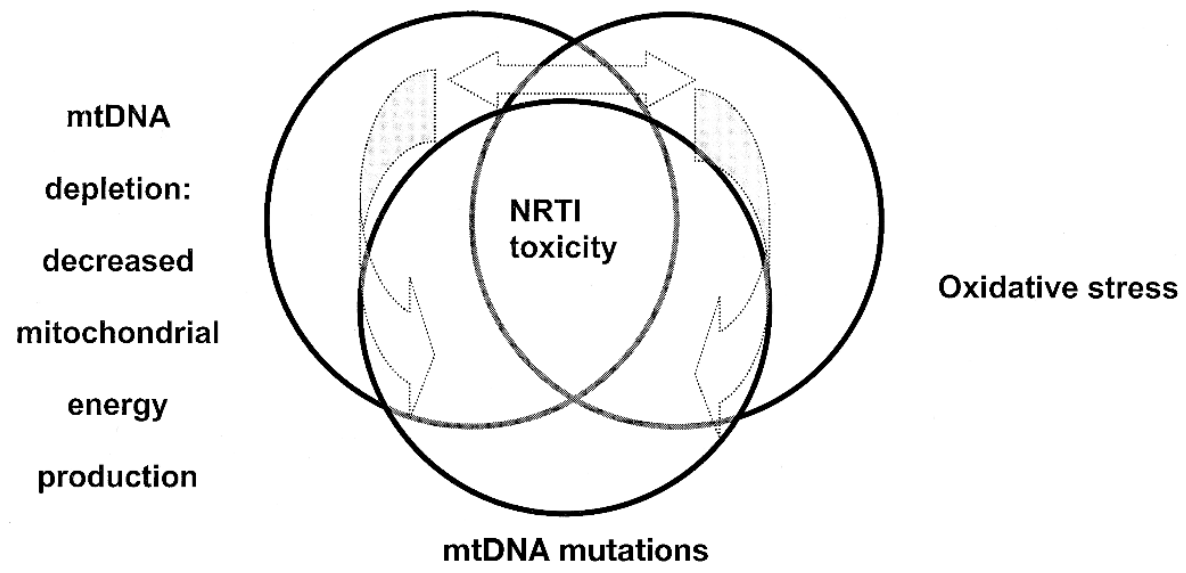

Figure 1.

Mitochondrial dysfunction includes the interaction of decreased energy production, mitochondrial oxidative stress, and mtDNA mutations. The initiating step seems to be decreased energy production, based on clinical and biological manifestations. mtDNA, mitochondrial DNA; NRTI, nucleoside reverse transcriptase inhibitors.

In the mitochondrial dysfunction hypothesis, the polymerase function of DNA pol- $\gamma$ is fundamental to the first proposed mechanism of NRTI toxicity, ie, decreased energy production secondary to decreased mtDNA abundance. When DNA pol- $\gamma$ activity is inhibited by NRTI triphosphates, mtDNA depletion results. This also suggests that NRTI toxicity may be cumulative and toxic manifestations increase with duration of exposure.

The two-subunit DNA pol- $\gamma$ is highly processive because of its accessory subunit. This high processivity allows the DNA pol- $\gamma$ complex to replicate the entire mitochondrial genome in one binding event (Lim et al, 1999). Processivity of DNA pol- $\gamma$ may relate in part to heteroplasmy, an intracellular or intramitochon- drial mix of normal and mutant mitochondrial DNA molecules (Gray and Wong, 1992; Wang et al, 1997) in $\mathrm{NRTI}$ toxicity in which truncated mtDNA fragments may be synthesized.

Because of the high processivity of DNA pol- $\gamma$, deletion mutants (truncated mtDNA templates) may be replicated more quickly and efficiently than native mtDNA counterparts (Lim et al, 1999; Wang et al, 1997). The abundance of defective mtDNA may increase to a point at which a threshold of energy depletion may be reached and symptoms become manifested. This threshold effect on energetics in $\mathrm{NRTI}$ toxicity is analogous to that seen with heritable mitochondrial illnesses, including those that include mtDNA depletion (Moraes et al, 1991; Wallace, 1992a, 
1992b). One potential defense against NRTI toxicity exists in the $3^{\prime} \rightarrow 5^{\prime}$ exonuclease within the enzyme. This exonucleolytic function (Kunkel and Mosbaugh, 1989; Kunkel and Soni, 1988) is inhibited by nucleoside 5'-monophosphates (Kaguni et al, 1988).

\section{Mitochondrial Energy Depletion: The First Step in Mitochondrial Dysfunction from NRTI Therapy}

Zidovudine (AZT 3'-azido-2',3'-deoxythymidine), zalcitabine (ddC 2',3'-dideoxycytidine), didanosine (ddl 2',3'-dideoxyinosine), stavudine (d4T 2',3'-didehydro3 '-dideoxythymidine), and lamivudine (3TC; 3 thiacytidine; cis-1-[2'-hydroxymethyl-5'-(1, 3oxathiolanyl)] cytosine) are formidable NRTIs that also serve as tools in vitro and in vivo in biomedical and cell biological models of inhibition of DNA pol- $\gamma$.

Agents that showed promise in AIDS salvage therapy (including fluoro-dideoxyadenosine [FDDA], 2'fluoro-2',3'-dideoxyadenosine) or in treatment of chronic hepatitis B infection, such as fialuridine (1-[2deoxy-2-fluoro- $\beta$-D-arabinofuranosyl]-5-iodouracil), were extremely toxic to liver, skeletal, and cardiac muscle, and peripheral nerve in clinical trials. The extent of mitochondrial toxicity was so profound that premature death and hepatic failure in some patients required early termination of clinical trials and abandonment of these pharmacological agents because of mitochondrial toxicity.

The mitochondrial dysfunction hypothesis is an expansion of earlier work. In essence, it incorporates the "DNA pol- $\gamma$ hypothesis" (Lewis and Dalakas, 1995), oxidative stress, and "acquired" mtDNA mutations as events in a pathophysiological continuum related to energy depletion. Acquired mitochondrial diseases may affect mtDNA replication at the level of competition with native nucleotide pools and at the nucleotide binding site of the polymerase. They ultimately result in depletion of mtDNA in affected tissues. The phenotypic results include deleterious effects on mitochondrial structure and function in selected targets, much like what may be expected in some genetic mitochondrial illnesses. Depletion of mtDNA is important to the toxic process mechanistically and seems to be a diagnostic hallmark (Arnaudo et al, 1991; Lewis et al, 1992). The NRTI monophosphate serves as either a mtDNA chain terminator or a nonfunctional base in newly replicating mtDNA (Lewis and Dalakas, 1995).

The DNA pol- $\gamma$ hypothesis (Lewis and Dalakas, 1995) relates clinical observations, and biochemical, pharmacological, and pathological data. For example, one aspect of the hypothesis focuses on energy deprivation. An analogous hypothesis was effectively used by Katz (1998) to explain the role of mitochondrial alterations in the development of low output congestive heart failure. The inability of mitochondria to function normally in that setting relates to decreased cardiac performance. Energy deprivation, possibly the initiating step of NRTI toxicity based on mtDNA depletion, relates decreased energy abundance in tissues (eg, heart) to decreased abundance of normal, functional mitochondria. The OXPHOS paradigm, articulated by Wallace (1992a, 1992b), states that tissue requirements for oxidative phosphorylation and threshold effects of dysfunction appear to be integral to the development of symptoms in genetic illnesses of mtDNA. It follows that NRTI toxicity is cumulative in its effect on mtDNA. Clinical thresholds may be crucial in the acquired forms of mitochondrial illnesses that result from NRTI toxicity.

Corollaries of the DNA pol- $\gamma$ hypothesis suggest that other pharmacological and cell biological processes are disturbed to yield mtDNA depletion. The subcellular availability and abundance of the NRTI in the target tissue, the ability of the NRTI to become monophosphorylated, and its subsequent ability to serve as a substrate for phosphorylation to the triphosphate are all crucial to the clinical events. The ability of the NRTI triphosphate to inhibit DNA pol- $\gamma$ and the metabolic requirements of the tissues for oxidative phosphorylation also play key roles.

\section{Oxidative Stress: The Second Step}

Although energy depletion from altered mtDNA replication in NRTI toxicity is a logical consequence (Lewis et al, 1991, 1992, 1994a, 1994b, 1996, 1997, 2000; Lewis and Dalakas, 1995), related events of oxidative stress also impact on energetics and mtDNA replication. Oxidative stress is defined as an imbalance between the production of reactive oxygen species (ie, superoxide, hydrogen peroxide, lipid peroxides, hydroxyl radical, and peroxynitrite) and the cellular antioxidant defenses that prevent damage from those moieties (Betteridge, 2000). Mitochondria are logical targets for oxidative stress based on their ability to generate reactive oxygen species and may be primarily involved in oxidative stress associated with AIDS treatment. Chronic AZT treatment induces oxidative damage of skeletal muscle in mice (de la Asuncion et al, 1998) and in rats treated acutely with AZT (Szabados et al, 1999).

Under physiological conditions, reactive oxygen species are produced principally by the mitochondria during OXPHOS. During OXPHOS, approximately $2 \%$ to $4 \%$ of electron flux results in the reduction of oxygen to superoxide instead of water. Mitochondria generate superoxide and hydrogen peroxide (Boveris and Chance, 1973; Freeman and Crapo, 1981; Turrens et al, 1982). Importantly, disruption of electron flow through the electron transport complexes can greatly increase reactive oxygen production. Superoxide is generated at both the NADH dehydrogenase and the ubiquinone Q-cytochrome b complexes (Fig. 2). Mitochondrial hydrogen peroxide is rapidly formed from superoxide by spontaneous dismutation $\left(10^{5} \mathrm{M}^{-1} \mathrm{~s}^{-1}\right)$ or by mitochondrial manganese superoxide dismutase $\left(10^{9} \mathrm{M}^{-1} \mathrm{~s}^{-1}\right)$. Hydroxyl radicals have been detected at sites where superoxide and hydrogen peroxide are formed in the mitochondria (Nohl et al, 1982) and are produced in liver mitochondria from septic rats (Taylor et al, 1995). 


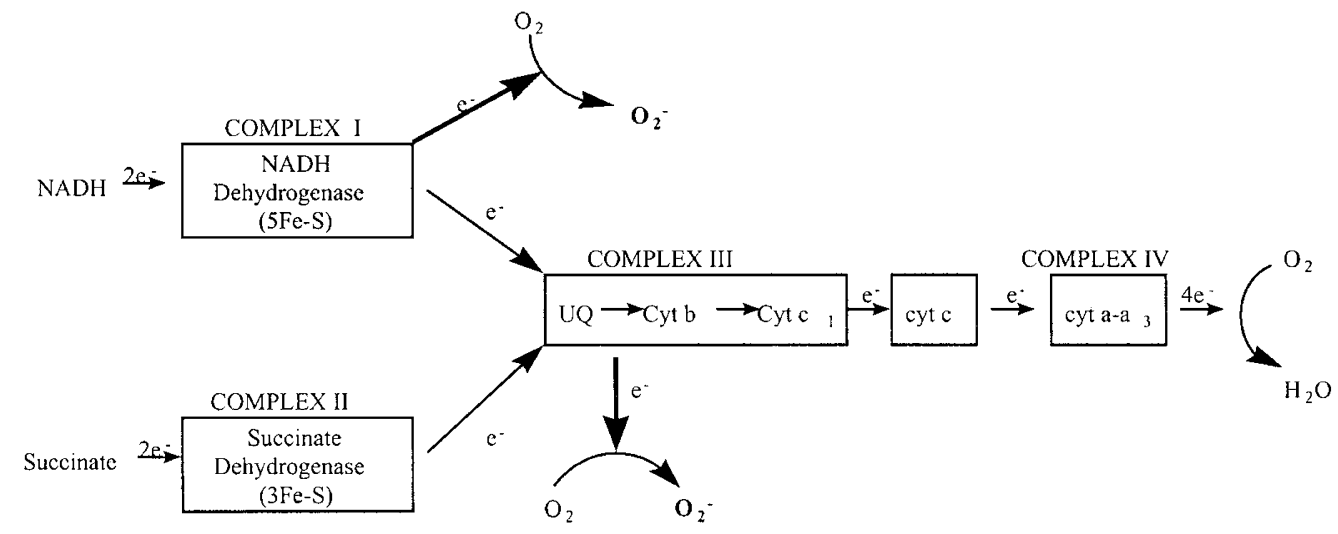

Figure 2.

Simplified scheme of the mitochondrial respiratory chain showing potential sites of superoxide anion $\left(\mathrm{O}_{2}^{-}\right)$formation. Cyt, cytochrome; UQ, ubiquinone; Fe-S, iron sulfur center.

Mitochondria concentrate iron for incorporation into cytochromes and non-heme-iron proteins (Tangeras et al, 1980). Mitochondrial iron is found in iron (Fe-S)containing enzymes such as aconitase. Reactive oxygen species can release Fe (II) from aconitase (Flint et al, 1993) and this Fe (II) can bind to mtDNA and provide a site for the production of powerful oxidants immediately adjacent to this critical target. Thus, oxidative stress affects mtDNA replication by altering mtDNA templates through oxidation. It should be noted that DNA pol- $\gamma$ is very susceptible to oxidative degeneration in vitro and may reflect the biological phenomenon.

Nitric oxide is another reactive oxygen species that is generated by both calcium-calmodulin-dependent (constitutive) and calcium-independent (inducible) forms of nitric oxide synthase. Nitric oxide can affect energy production because it has been shown to tightly bind and inhibit cytochrome oxidase (Brown, 2000). Nitric oxide's direct toxicity is modest but is greatly enhanced by reaction with superoxide to form peroxynitrite (Beckman and Koppenol, 1996). The protonation and decomposition of peroxynitrite to more reactive species is an important mechanism by which nitric oxide can damage DNA (Radi et al, 1991). Fortunately, mitochondria contain antioxidants to protect against damage from reactive oxygen species. A manganese superoxide dismutase (MnSOD) catalyzes the dismutation of superoxide into hydrogen peroxide and oxygen at a rate that approaches the diffusion limit. MnSOD eliminates superoxide but generates hydrogen peroxide that can also produce injury (Buckley et al, 1987). Mitochondria eliminate hydrogen peroxide principally by endogenous glutathione peroxidase. This enzyme converts hydrogen peroxide to water and oxidizes glutathione (Asayama et al, 1996; Marinho et al, 1997). Glutathione reductase and NADPH (from the pentose shunt) recycle oxidized glutathione. Under normal conditions these enzyme systems prevent the build-up of hydrogen peroxide and limit the formation of potentially more reactive species (eg, hydroxyl radical) (Halliwell and Gutteridge, 1985).

\section{Mutations of mtDNA: The Third Step}

In addition to NRTI-induced energy deprivation, oxidative damage to mtDNA by respiration-linked reactive oxygen species may relate to damage of cardiac myocytes and development of cardiomyopathy (CM) (reviewed in Linnane et al, 1989; Miquel, 1992). Reactive oxygen species such as hydrogen peroxide, hydroxyl radical, and others are generated close to the inner membrane of the mitochondria and can react with and oxidize mtDNA (Freese et al, 1967). This makes the mtDNA a likely target for oxidative stress.

mtDNA from rat liver has more than 100 times the level of oxidative DNA damage than does nuclear DNA. Differences in oxidative damage between nDNA and mtDNA may relate to (a) lack of known repair enzymes for mtDNA error excision, (b) a lack of histones protecting mtDNA, and (c) a subcellular proximity of mtDNA to these oxidants. Exposure of DNA to superoxide-generating systems causes extensive strand breakage and degradation of deoxyribose (Brawn and Fridovich, 1981). Additionally, peroxynitrite is a potent initiator of DNA strand breaks (Szabo et al, 1996) and causes DNA base modifications (Spencer et al, 1996). On a mass-action basis, random mtDNA mutations would likely inactivate complex I, because of the significant contribution from mtDNAencoded elements. Moreover, deficiency of complex I proteins could amplify superoxide formation and increase oxidative stress (Cortopassi et al, 1996).

Oxidation of mtDNA by hydroxyl radicals results in the formation of the oxidized base 8-hydroxydeoxyguanosine (8-OHdG). $8-\mathrm{OHdG}$ is present in hepatic mtDNA at 16-fold higher levels than in corresponding nuclear DNA (Richter, 1988; Richter et al, 1988). In human hearts, similar observations were made (Hayakawa et al, 1992). Base modification can lead to mispairing and point mutation (Pavlov et al, 1994). It follows stochastically that, during any given oxidative event, mtDNA will sustain more damage than nuclear DNA (Ames et al, 1993; Yakes and Van Houten, 1997). The number of oxidative hits in rat DNA is estimated at about 100,000 per cell per day. Enzymes for nuclear 
DNA repair efficiently remove most, but not all, of the adducts in nDNA (Ames et al, 1993). Although most of the components of a mitochondrial base excision repair system have been identified (Pinz and Bogenhagen, 1998), it is unclear how efficiently this repair removes the wide spectrum of adducts that may result from oxidative damage. Mitochondrial oxidative damage was supported indirectly by the coexistence of malondialdehyde on (or near) the inner mitochondrial membrane (Fleming et al, 1982). Its interaction with mtDNA could lead to cross-linking, deletion errors in transcription, or mtDNA polymerization. In oxidative stress, abundance of $8-\mathrm{OHdG}$ is higher in mtDNA than in nuclear DNA (Kuchino et al, 1987). This may relate to the abundance of mtDNA deletions (Hattori et al, 1991; Hayakawa et al, 1992). A random accumulation of mtDNA defects may result in myocytes with an array of oxidative capacity ranging from normal to severely impaired. This would effectively produce a myocardial "bioenergy mosaic" in NRTI-treated cells in the aging heart (Linnane et al, 1992). Such a mosaic may be absent during histochemical analysis in which a spectrum of activity may be seen in a given tissue (eg, myocardial cytochrome c oxidase activity as a function of aging) (Muller-Hocker, 1989). Pathophysiological events would not occur until the threshold of damage were severe enough to affect organ function (Wallace, 1992a).

\section{NRTI Pharmacological Classification}

Pharmacologically, NRTIs have been divided into classes of mtDNA replication inhibitors according to the relative importance of DNA chain termination, or the internalization of the analog into nascent mtDNA and substitution for the natural base (Kakuda, 2000; Parker and Cheng, 1994; Wright and Brown, 1990). One class inhibits mtDNA replication in ways that resemble the action of fialuridine (FIAU). This suggests that the NRTI monophosphate is incorporated into mtDNA. FIAU, FIAC (1-[2-deoxy-2-fluoro- $\beta$-Darabinofuranosyl]-5-iodocytosine), FMAU (1-[2-deoxy-2fluoro- $\beta$-D-arabinofuranosyl]-5-methyluracil), and FEAU (1[2-deoxy-2-fluoro- $\beta$-D-arabinofuranosyl]-5-ethyluracil) each demonstrated efficacy in viral disease models (Fourel et al, 1990), and many of their triphosphates inhibit mammalian DNA pol- $\gamma$ in vitro (Lewis et al, 1994a). With these agents, competition with the native nucleotide and NRTI at the nucleotide binding site of DNA pol- $\gamma$ appears to be a critical event.

The second type of NRTI is represented by some dideoxynucleosides, such as AZT, ddC, and D4T. With such agents, 5'-triphosphates are substrates for mtDNA synthesis by DNA pol- $\gamma$. They compete with the natural nucleotides (as above) and also terminate nascent mtDNA chains because they lack 3'-hydroxyl groups $\left(3^{\prime}-\mathrm{OH}\right)$ for continued mtDNA polymerization. mtDNA replication defects from NRTI toxicity may be reversible in some cases. The $3^{\prime} \rightarrow 5^{\prime}$ exonuclease of DNA pol- $\gamma$ may excise the inserted NRTI monophosphate at the time of its insertion into nascent mtDNA if the NRTI is recognized as an erroneous substitute. If the NRTI is not capable of being recognized, it remains in the chain and mtDNA synthesis ceases because the $3^{\prime}-\mathrm{OH}$ necessary for DNA replication is absent in dideoxy NRTIs.

Terminally incorporated AZT monophosphate is not removed by the $3^{\prime} \rightarrow 5^{\prime}$ exonuclease of Saccharomyces cerevisiae DNA pol- $\gamma$ (Eriksson et al, 1995). Similar results were found using porcine DNA pol- $\gamma$ against dideoxynucleotide termini (Longley and Mosbaugh, 1991). Human DNA pol- $\gamma$ removes chain terminators poorly compared with normal nucleotides. AZTmonophosphate is the most persistent chain terminator to DNA pol- $\gamma$ exonuclease activity (Lim and Copeland, 2001). It is possible that this could be significant mechanistically in the observed mitochondrial toxicity of DNA by AZT and related NRTIs.

In the case of non-dideoxy-NRTIs, the situation has molecular similarities to the biological condition. Accordingly, use of these compounds has potentially more hazardous consequences, some of which have been observed in humans. Postreplicational repair mechanisms that remove the internally incorporated NRTI monophosphate are incompletely understood, and damage to mtDNA is likely to be more difficult to reverse.

This biochemical point was substantiated in a tragic National Institutes of Health $(\mathrm{NIH})$ clinical trial using FIAU in patients with chronic hepatitis $b$ virus infection. mtDNA replication was profoundly disturbed, principally in the liver, and this resulted in many patient deaths (with or without liver transplant). Incorporated FIAUMP (or FIAU metabolites) could be released from degraded DNA. We demonstrated that "adenosine tracts" were analogous to template-related "hot spots" that were particularly sensitive to mtDNA replication inhibition and resembled those found in some heritable mitochondrial diseases (Wallace, 1992a, 1992b) because they altered mtDNA synthesis. Adenosine tracts in DNA templates inhibit the incorporation of fialuridine monophosphate into DNA in vitro (Lewis et al, 1994b).

\section{Experimental NRTI Toxicity}

Table 1 highlights some of the studies in the literature. It should be noted that a few studies have implicated other mechanisms in NRTI mitochondrial toxicity. These include inhibition of adenine nucleotide translocator, NADH-cytochrome-reductase, mitochondrial permeability transition, and NADH oxidase.

In studies that suggested mtDNA replication was affected, kinetics were performed. Incubation of AZT triphosphate with DNA pol- $\gamma$ in vitro resulted in mixed kinetics with a competitive $\mathrm{K}_{\mathrm{i}}$ of $1.8 \pm 0.2 \mu \mathrm{M}$ and a noncompetitive $\mathrm{K}_{\mathrm{i}}$ of $6.8 \pm 1.7 \mu \mathrm{M}$. In studies by others, AZT triphosphate inhibited DNA pol- $\gamma$ activity by approximately $30 \%$ at $4 \mu \mathrm{M}$, compared with $80 \%$ inhibition of reverse transcriptase activity at the same concentration in vitro (Konig et al, 1989). A mixed inhibition pattern also was determined for inhibition of cardiac DNA pol- $\gamma$ by D4T triphosphate, but with a much lower $\mathrm{K}_{\mathrm{i}}$ s (Lewis and Tankersley, 1995). 
Human DNA pol- $\gamma$ is inhibited by $50 \%$ with $20 \mu \mathrm{M}$ AZT triphosphate in a reverse transcriptase assay ( $\mathrm{Lim}$ and Copeland, 2001). Gray et al (1995) showed that Hela cell DNA pol- $\gamma$ incorporated 3TC triphosphate nearly as well as ddC triphosphate into DNA. Martin et al (1994) compared the inhibition kinetics of human DNA polymerase $\alpha, \beta$ and found DNA pol- $\gamma$ to be highly inhibited by dideoxynucleotide triphosphates, D4T triphosphate, and fluoro-substituted analogs. AZT triphosphate, 3TC triphosphate, and carbovir triphosphate were moderate inhibitors of DNA pol- $\gamma$ in vitro. Martin et al (1994) also demonstrated that ddC, D4T, and FIAU inhibited mtDNA synthesis in vivo below known physiological levels.

\section{AZT Myopathy: Dideoxy NRTI Toxicity}

AZT causes a cumulative mitochondrial skeletal myopathy in adult AIDS patients (Dalakas et al, 1990). It is a bona fide complication, (Groopman, 1990; Till and MacDonell, 1990) with characteristic microscopic "ragged red fibers" (Shoubridge, 1994) and ultrastructural paracrystalline inclusions (Dalakas et al, 1990) that result from subsarcolemmal accumulation of mitochondria in the skeletal muscle with long-term, high-dose treatment in adult AIDS patients. Mitochondria are enlarged and swollen ultrastructurally and contain disrupted cristae and occasional paracrystalline inclusions (Lamperth et al, 1991; Lewis et al, 1991; Lewis and Dalakas, 1995; Pezeshkpour et al, 1991).

Extracts of muscle biopsy specimens of AZTtreated patients revealed decreased skeletal muscle mtDNA. Mitochondrial dysfunction in AZT-induced myopathy results in inefficient use of long-chain fatty acids for $\beta$-oxidation. Fat droplets accumulate. AZT myopathy develops after at least 6 months of therapy and occurs in up to $17 \%$ of treated patients (Dalakas et al, 1994; Peters et al, 1993). Jay and Dalakas (1994) showed that it occurs with the high-dose therapy and with current low-dose regimens. In pediatric populations with AIDS, AZT skeletal myopathy is less frequently observed and may be masked by coexisting encephalopathy.

Clinical features include fatigue, myalgia, muscle weakness, wasting, and elevation of serum creatine kinase (Arnaudo et al, 1991; Dalakas et al, 1994). Clinical improvement accompanies histologic improvement and reversal of zidovudine-induced mtDNA changes (Arnaudo et al, 1991; Dalakas et al, 1994). Pathologic changes in AZT myopathy are reversible following discontinuation of the drug. Serum analytes that are elevated include lactate dehydrogenase, creatine kinase, and serum glutamicoxaloacetic transaminase. These changes occur after prolonged therapy (Bessen et al, 1988). Exercise decreases muscle phosphocreatine (detected by ${ }^{31} \mathrm{P}$ nuclear magnetic resonance) in AZT-treated patients (Sinnwell et al, 1995). Abnormal mitochondrial respiratory function is found. Enzyme histochemical analysis of muscle biopsies shows partial deficiency of cytochrome c oxidase activity (Chariot and Gherardi, 1991; Dalakas et al, 1994). A high lactate/pyruvate ratio (consistent with abnormal mitochondrial function) is seen in the blood of patients with AZT myopathy (Chariot et al, 1994). Assessment of muscle metabolism in vivo using magnetic resonance spectroscopy shows marked phosphocreatine depletion with slow recovery only in AZT-treated, HIV-positive patients (Sinnwell et al, 1995).

Cardiomyopathy $(\mathrm{CM})$ related to AZT and/or other antiretroviral therapy has been reported in AIDS. Conversely, discontinuation of NRTIs results in improved left ventricular function (Herskowitz et al, 1992). Clinical features of AZT CM resemble some of those previously described. AZT CM occurs after prolonged treatment. Clinical features include congestive heart failure, left ventricle dilatation, and reduced ejection fraction. In general, biopsy data in AZT CM is incomplete. One small study shows ultrastructural changes of intramyocytic vacuoles, myofibrillar loss, dilated sarcoplasmic reticulum, and disruption of mitochondrial cristae (d'Amati et al, 1992).

AZT CM may not be a key finding in neonates treated with AZT but remains a controversial issue. In large-scale studies of pediatric patients with AIDS and of neonates treated with AZT both in utero and perinatally, Lipshultz and colleagues $(1992,2000)$ reported that impaired cardiac function was not attributed to AZT. Myocardial biopsy findings were absent in any of those reported studies. In parallel, it should be emphasized that AZT-skeletal myopathy is uncommon in children with AIDS (Jay and Dalakas, 1994). Contrasting evidence in other reports suggests that AZT CM in pediatric patients may be more prevalent than previously reported (Domanski et al, 1995). In vivo data from Erythrocebus patas treated with $A Z T$ in utero suggest some evidence of a mitochondrial toxicity of AZT to heart and skeletal muscle that resembles those features described in experimental systems with rodents (Gerschenson et al, 2000).

Cell biologically, AZT decreases the abundance of mtDNA in human lymphoblastoid cells (Chen et al, 1991). In vitro, AZT $(25 \mu \mathrm{M})$ inhibits the incorporation of $\left[{ }^{3} \mathrm{H}\right]$ thymidine by $90 \%$ (Chen et al, 1991), and $1 \mu \mathrm{M}$ AZT inhibits it by $25 \%$ to $38 \%$ (Simpson et al, 1989). Selective loss of mtDNA occurs in MOLT-4F lymphoblasts exposed to ddC, AZT, and other dideoxynucleosides in vitro (Chen and Cheng, 1989; Chen et al, 1991; d'Amati and Lewis, 1994). In various human and rodent muscle cell lines, exposure to AZT causes abnormal mitochondria with extensive lipid accumulation.

Oral AZT decreases rat cardiac mtRNA and alters mitochondrial ultrastructure (Corcuera Pindado et al, 1994; Lamperth et al, 1991; Lewis et al, 1991, 1992; Semino-Mora et al, 1994). In similarly treated rats, AZT administration decreases mtDNA, mtRNA, and mitochondrial polypeptide expression, and alters mitochondrial ultrastructure in skeletal muscle (Lewis et al, 1992). Mitochondrial changes we observed in the AZT-treated rat heart and muscle are found in striated muscle of hamsters treated with AZT intraperitoneally (Reyes et al, 1991). Rats treated with AZT develop ultrastructural abnormalities in skeletal and cardiac muscle mitochondria associated with depression of 
muscle mtDNA and mitochondrial polypeptide synthesis, impaired cytochrome c reductase, and an uncoupling effect (Lamperth et al, 1991; Semino-Mora et al, 1994).

\section{FIAU: Toxicity of a Nondideoxy NRTI}

FIAU was the basis for a clinical trial in patients with chronic active hepatitis B virus. Although FIAU exhibits thorough virucidal activity, serious toxicity includes liver failure, (with liver transplantation: Brahams, 1994; Macilwain, 1994; Marshall, 1994; Swartz, 1995). Clinical manifestations include profound lactic acidosis, hepatic failure, skeletal and cardiac myopathy, pancreatitis, and neuropathy. Microvesicular hepatic steatosis is prominent. We show that FIAU triphosphate inhibits DNA pol- $\gamma$ (competitively with a nanomolar $\mathrm{K}_{\mathrm{i}}$ and that FIAU monophosphate is incorporated into DNA (Lewis et al, 1994a, 1996). FIAU and FMAU triphosphate demonstrate nanomolar, competitive $\mathrm{K}_{\mathrm{i}}$ values.

HepG2 cells treated with FIAU and FMAU result in each NRTI to be found in nuclear and mtDNA. Ultrastructural defects are found in mitochondria (Cui et al, 1995). mtDNA decrease in abundance in HepG2 cells after 14 days' exposure to FIAU and FMAU (Lewis et al, 1996); FIAU and FMAU, but not FAU, cause mitochondrial structural defects in vitro after at least 2 weeks' treatment. Changes are visible on Oil-red-Ostained HepG2 monolayers. Morphologic changes correlate with lactate abundance in the medium (Levine and Lewis, 1995). In U937 or MOLT-4 cells treated with FIAU, a higher $I_{50}$ is found, with $1 \%$ to $2 \%$ replacement of cellular thymidine by fialuridine (Klecker et al, 1994).

Oil-red-O-stained heart samples from FIAU-treated woodchucks reveal neutral lipid droplets in cardiac myocyte cytoplasm. Ultrastructural evidence of mitochondrial destruction is seen. The steady-state abundance of mtDNA in the liver, myocardium, skeletal muscle, and kidney is significantly decreased in tissue samples from fialuridine-treated woodchucks. The magnitude of the decreases varies among the tissues examined (Lewis et al, 1997; Tennant et al, 1998).

\section{Toxicity from Other NRTIs: Varying Tissue Targets}

Evidence for the toxicity of NRTIs in different organ systems is presented in tabular form (Table 1). Hepatic toxicity from AZT, ddl, and ddC was reported (Chattha et al, 1993; Freiman et al, 1993; Jolliet and Widmann, 1990). It is presumed to relate to toxicity to liver mitochondria. Fatal hepatomegaly with severe steatosis (Freiman et al, 1993), severe lactic acidosis (Chattha et al, 1993), and adult Reye's syndrome (Jolliet and Widmann, 1990) in AZT-treated HIV seropositive patients are all pathogenetically linked to AZT-induced hepatotoxicity. Clinical features resemble some of those seen in FIAU toxicity. The prevalence of metabolic abnormalities is increasing in AIDS patients treated with NRTI analogs, and the relationship to a variety of metabolic and cardiovascular changes in AIDS is being investigated more closely.

Treatment with certain NRTIs (d4T/3TC) results in anion gap acidosis (Moore et al, 2000a). Moreover, the lactic acidosis/hepatic steatosis syndrome may be more common than previously appreciated in adults (Boubaker et al, 2000; Lonergan et al, 2000; Ter Hofstede et al, 2000) and children (Church et al, 2000) treated with NRTIs. d4T treatment causes lipodystrophy (Saint-Marc et al, 1999). Mechanisms may involve altered mitochondrial biogenesis and/or oxidative changes and possibly adipocyte apoptosis (Harrison, 1997; Lewis and Dalakas, 1995). Recently, we demonstrated arterial dysfunction in $\mathrm{FVB} / \mathrm{n}$ mice treated with AZT (Sutliff et al, 2000), which may be another important target of toxicity. The use of hydroxyurea in HAART regimens has been associated with neuropathy, pancreatitis, and acute liver failure (Havlir et al, 2000; Moore et al, 2000b).

NRTIs have peripheral neuropathies as side effects (Cohen et al, 1994; Lewis and Dalakas, 1995). Doserelated, painful peripheral neuropathies occur in the majority of patients treated with ddC in doses of 0.03 to $0.09 \mathrm{mg} / \mathrm{kg} /$ day (Berger et al, 1993; Dubinsky et al, 1989; Merigan et al, 1989; Yarchoan et al, 1990). Peripheral neuropathy with ddl was unexpected, based upon preclinical data (Anderson et al, 1994). It was observed in $3 \%$ to $22 \%$ (Cooley et al, 1990; Lambert et al, 1990) of patients after 8 weeks. Peripheral neuropathy occurs in $55 \%$ of d4T-treated patients after up to 46 weeks' treatment. Clinically, distal dysesthesias, areflexia, distal sensory loss, and mild muscle weakness are common. Axonal involvement is present. Sural nerve biopsies for patients with ddC neuropathy show axonal degeneration and mitochondria with disrupted cristae. These findings resemble those of experimentally induced neuropathy in ddCfed rabbits (Anderson et al, 1994). Lamivudine has an associated peripheral neuropathy (Cupler and Dalakas, 1995).

ddC decreases the abundance of mtDNA in PC12 mouse neuronal cell lines in vitro (Keilbaugh et al, 1993) and cultured cells treated with ddC, d4T, or ddl (Medina et al, 1994). We found decreased abundance of mtDNA in HTB11 neuroblastoma cells treated with ddC, ddl, or d4T. In vitro, Dalakas' group showed that AZT increases the abundance of lactate in the culture medium and causes mitochondrial abnormalities in myotubes (Semino-Mora et al, 1994). Although ddC and ddl have not yet been associated with cardiac lesions similar to those associated with AZT (Meyer and Lewis, 1993), administration of ddC to rabbits results in dose-related structural damage to the Schwann cells of the peripheral nerves (Anderson et al, 1992, 1994). This so-called "Schwannopathy" involves mitochondrial changes with some similarities to those found with AZT myopathy.

\section{Summary}

NRTI toxicity is now an important clinical problem with long-term significance to AIDS patients. Mechanisms 
likely relate to energy depletion, oxidative stress, and mtDNA mutations. Analogously to treatment of other serious infectious agents, combinations of multiple anti-HIV-1 drugs are used to target different viral proteins or points in the virus-host life cycle (Lange, 1995; De Clercq, 1997) and may create combined toxicities to mitochondria. As current clinical guidelines recommend combined therapy, usually including NRTI (Centers for Disease Control and Prevention, 1999), such regimens may be important to the development of mitochondrial toxicity in new tissue targets as treatment is prolonged because of the increased longevity of patients with AIDS. [The following references were cited only in Table 1: Barile et al, 1994, 1997; Benbrik et al, 1997; Browne et al, 1993; Chen and Cheng, 1992; Cherrington et al, 1995; Corcuera et al, 1996; Cui et al, 1997; Dalakas et al, 1990; Elimadi et al, 1997. The following references were cited only in Table 1: Feldman and Anderson, 1994; Feldman et al, 1992; Hart et al, 1992; Hertzberg et al, 1992; Hobbs et al, 1992, 1995; Institute of Medicine (US) Committee to Review the Fialuridine (FIAU/FIAC) Clinical Trials, 1995; Izuta et al, 1991. The following references were cited only in Table 1: Modica-Napolitano, 1993; Nusbaum and Joseph, 1996; Parker et al, 1991; Pereira et al, 1998; Richardson et al, 1994; Schroder et al, 1996; Stevenson et al, 1995; Tsai et al, 1994. The following references were cited only in Table 1: Wang et al, 1996; White et al, 1989.]

\section{Acknowledgements}

We thank Kelly Sjögren for preparing this manuscript.

\section{References}

Ames BN, Shigenaga MK, and Hagen TM (1993). Oxidants, antioxidants, and the degenerative diseases of aging. Proc Natl Acad Sci USA 90:7915-7922.

Anderson TD, Davidovich A, Arceo R, Brosnan C, Arezzo J, and Schaumburg $H$ (1992). Peripheral neuropathy induced by 2',3'-dideoxycytidine. A rabbit model of 2',3'-dideoxycytidine neurotoxicity. Lab Invest 66:63-74.

Anderson TD, Davidovich A, Feldman D, Sprinkle TJ, Arezzo J, Brosnan C, Calderon RO, Fossom LH, DeVries JT, and DeVries GH (1994). Mitochondrial schwannopathy and peripheral myelinopathy in a rabbit model of dideoxycytidine neurotoxicity. Lab Invest 70:724-739.

Arnaudo E, Dalakas M, Shanske S, Moraes CT, DiMauro S, and Schon EA (1991). Depletion of muscle mitochondrial DNA in AIDS patients with zidovudine-induced myopathy. Lancet 337:508-510.

Asayama K, Yokota S, Dobashi K, Kawada Y, Nakane T, Kawaoi A, and Nakazawa S (1996). Immunolocalization of cellular glutathione peroxidase in adult rat lungs and quantitative analysis after postembedding immunogold labeling. Histochem Cell Biol 105:383-389.

Barile M, Valenti D, Hobbs GA, Abruzzese MF, Keilbaugh SA, Passarella S, Quagliariello E, and Simpson MV (1994). Mechanisms of toxicity of 3'-azido-3'-deoxythymidine. Its interac- tion with adenylate kinase. Biochem Pharmacol 48:14051412.

Barile M, Valenti D, Passarella S, and Quagliariello E (1997). 3'-Azido-3'-deoxythmidine uptake into isolated rat liver mitochondria and impairment of ADP/ATP translocator. Biochem Pharmacol 53:913-920.

Beckman JS and Koppenol WH (1996). Nitric oxide, superoxide, and peroxynitrite: The good, the bad, and ugly. Am J Physiol 271:C1424-1437.

Benbrik E, Chariot P, Bonavaud S, Ammi-Said M, Frisdal E, Rey C, Gherardi R, and Barlovatz-Meimon G (1997). Cellular and mitochondrial toxicity of zidovudine (AZT), didanosine (ddl) and zalcitabine (ddC) on cultured human muscle cells. J Neurol Sci 149:19-25.

Berger AR, Arezzo JC, Schaumburg HH, Skowron G, Merigan T, Bozzette S, Richman D, and Soo W (1993). 2',3'dideoxycytidine (ddC) toxic neuropathy: A study of 52 patients. Neurology 43:358-362.

Bessen LJ, Greene JB, Louie E, Seitzman P, and Weinberg H (1988). Severe polymyositis-like syndrome associated with zidovudine therapy of AIDS and ARC (Letter). N Engl J Med 318:708.

Betteridge DJ (2000). What is oxidative stress? Metabolism 49:3-8.

Boubaker K, Sudre P, Flepp m, Furrer H-J, Haensel A, Hirschel B, Boggian K, Chave J-P, Bernasconi E, Opravil M, Rickenbach M, and Telenti A (2000). Hyperlactatemia and antiretroviral therapy in the Swiss HIV Cohort Study (SHCS). Paper presented at 7th Conference on Retroviruses and Opportunistic Infections. San Francisco, CA, January 30February 2, 2000.

Boveris A and Chance B (1973). The mitochondrial generation of hydrogen peroxide. General properties and effect of hyperbaric oxygen. Biochem J 134:707-716.

Brahams D (1994). Deaths in US fialuridine trial (News). Lancet 343:1494-1495.

Brawn K and Fridovich I (1981). DNA strand scission by enzymically generated oxygen radicals. Arch Biochem Biophys 206:414-419.

Brinkman K, Smeitink JA, Romijn JA, and Reiss P (1999). Mitochondrial toxicity induced by nucleoside-analogue reverse- transcriptase inhibitors is a key factor in the pathogenesis of antiretroviral-therapy-related lipodystrophy (Comment). Lancet 354:1112-1115.

Brinkman K, ter Hofstede HJ, Burger DM, Smeitink JA, and Koopmans PP (1998). Adverse effects of reverse transcriptase inhibitors: Mitochondrial toxicity as common pathway (Editorial). AIDS 12:1735-1744.

Brown GC (2000). Nitric oxide as a competitive inhibitor of oxygen consumption in the mitochondrial respiratory chain. Acta Physiol Scand 168:667-674.

Browne MJ, Mayer KH, Chafee SB, Dudley MN, Posner MR, Steinberg SM, Graham KK, Geletko SM, Zinner SH, and Denman SL (1993). 2',3'-didehydro-3'-deoxythymidine (d4T) in patients with AIDS or AIDS-related complex: A phase I trial. $J$ Infect Dis 167:21-9.

Buckley BJ, Tanswell AK, and Freeman BA (1987). Liposome-mediated augmentation of catalase in alveolar type II cells protects against $\mathrm{H}_{2} \mathrm{O}_{2}$ injury. J Appl Physiol 63:359-367. 
Carr A, Samaras K, Thorisdottir A, Kaufmann GR, Chisholm DJ, and Cooper DA (1999). Diagnosis, prediction, and natural course of HIV-1 protease-inhibitor- associated lipodystrophy, hyperlipidaemia, and diabetes mellitus: A cohort study (See comments). Lancet 353:2093-2099.

Carrodeguas JA, Kobayashi R, Lim SE, Copeland WC, and Bogenhagen DF (1999). The accessory subunit of Xenopus laevis mitochondrial DNA polymerase gamma increases processivity of the catalytic subunit of human DNA polymerase gamma and is related to class II aminoacyl-tRNA synthetases. Mol Cell Biol 19:4039-4046.

Centers for Disease Control and Prevention (1999). Guidelines for the use of antiretroviral agents in HIV-infected adults and adolescents. Department of Health and Human Services (DHHS): MMWR 47 (RR-5), 42-82.

Chariot P and Gherardi R (1991). Partial cytochrome c oxidase deficiency and cytoplasmic bodies in patients with zidovudine myopathy. Neuromuscul Disord 1:357-363.

Chariot P, Monnet I, Mouchet M, Rohr M, Lefaucheur JP, Dubreuil-Lemaire ML, Chousterman M, and Gherardi R (1994). Determination of the blood lactate:pyruvate ratio as a noninvasive test for the diagnosis of zidovudine myopathy. Arthritis Rheum 37:583-586.

Chattha G, Arieff Al, Cummings C, and Tierney LM Jr (1993). Lactic acidosis complicating the acquired immunodeficiency syndrome (See comments). Ann Intern Med 118:37-39.

Chen CH and Cheng YC (1989). Delayed cytotoxicity and selective loss of mitochondrial DNA in cells treated with the anti-human immunodeficiency virus compound 2',3'dideoxycytidine. J Biol Chem 264:11934-11937.

Chen $\mathrm{CH}$ and Cheng YC (1992). The role of cytoplasmic deoxycytidine kinase in the mitochondrial effects of the anti-human immunodeficiency virus compound, 2',3';dideoxycytidine. J Biol Chem 267:2856-2859.

Chen CH, Vazquez-Padua M, and Cheng YC (1991). Effect of anti-human immunodeficiency virus nucleoside analogs on mitochondrial DNA and its implication for delayed toxicity. Mol Pharmacol 39:625-628.

Cherrington JM, Allen SJW, Bischofberger N, and Chen MS (1995). Kinetic interaction of the diphosphates of 9-(2phosphonyl-methoxyethyl) adenine and other anti-HIV active purine congeners with HIV reverse transcriptase and human DNA polymerases alpha, beta and gamma. Antiviral Chem Chemother 6:217-221.

Church J, Mitchell W, Gonzalez-Gomez I, Boles R, Wetzel R, and Vu T (2000). Near-fatal metabolic acidosis, liver failure in mitochondrial $(\mathrm{mt})$ DNA depletion in an HIV-infected child treated with combination antiretroviral therapy (ART). Paper presented at 7th Conference on Retroviruses and Opportunistic Infections. San Francisco, CA, January 30-February 2, 2000.

Cohen P, Sande M, and Volberding P (1994). The AIDS knowledge Base. Boston: Little Brown and Company, 5.616.62.

Cooley TP, Kunches LM, Saunders CA, Ritter JK, Perkins CJ, McLaren C, McCaffrey RP, and Liebman HA (1990). Oncedaily administration of $2^{\prime}, 3^{\prime}$-dideoxyinosine (ddl) in patients with the acquired immunodeficiency syndrome or AIDSrelated complex. Results of a Phase I trial (See comments]. N Engl J Med 322:1340-1345.
Corcuera Pindado MT, Lopez Bravo A, Martinez-Rodriguez R, Picazo Talavera A, Gomez Aguado F, Roldan Contreras M, Perez Alvarez MJ, Fernandez Garcia A, and Alonso Martin MJ (1994). Histochemical and ultrastructural changes induced by zidovudine in mitochondria of rat cardiac muscle. Eur J Histochem 38:311-318.

Corcuera T, Alonso MJ, Picazo A, Gomez F, Roldan M, Abad M, Munoz E, and Lopez-Bravo A (1996). Hepatic Morphological alterations induced by zidovudine (ZDV) in an experimental model. Pathol Res Pract 192:182-187.

Cortopassi G, Liu Y, and Hutchin T (1996). Degeneration of human oncogenes and mitochondrial genes occurs in cells that exhibit age-related pathology. Exp Gerontol 31:253-265.

Cui L, Locatelli L, Xie MY, and Sommadossi JP (1997). Effect of nucleoside analogs on neurite regeneration and mitochondrial DNA synthesis in PC-12 cells. J Pharmacol Exp Ther 280:1228-1234.

Cui L, Yoon S, Schinazi RF, and Sommadossi JP (1995). Cellular and molecular events leading to mitochondrial toxicity of 1-(2-deoxy-2-fluoro-1-beta-D-arabinofuranosyl)-5iodouracil in human liver cells. J Clin Invest 95:555-563.

Cupler EJ and Dalakas MC (1995). Exacerbation of peripheral neuropathy by lamivudine. Lancet 345:460-461.

Dalakas MC, Illa I, Pezeshkpour GH, Laukaitis JP, Cohen B, and Griffin JL (1990). Mitochondrial myopathy caused by long-term zidovudine therapy (See comments). N Engl J Med 322:1098-1105.

Dalakas MC, Leon-Monzon ME, Bernardini I, Gahl WA, and Jay CA (1994). Zidovudine-induced mitochondrial myopathy is associated with muscle carnitine deficiency and lipid storage (See comments). Ann Neurol 35:482-487.

d'Amati G, Kwan W, and Lewis W (1992). Dilated cardiomyopathy in a zidovudine-treated AIDS patient. Cardiovasc Pathol 1:317-320.

d'Amati G and Lewis W (1994). Zidovudine causes early increases in mitochondrial ribonucleic acid abundance and induces ultrastructural changes in cultured mouse muscle cells. Lab Invest 71:879-884.

De Clercq E (1997). In search of a selective antiviral chemotherapy. Clin Microbiol Rev 10:674-693.

de la Asuncion JG, del Olmo ML, Sastre J, Millan A, Pellin A, Pallardo FV, and Vina J (1998). AZT treatment induces molecular and ultrastructural oxidative damage to muscle mitochondria. Prevention by antioxidant vitamins. J Clin Invest 102:4-9.

Domanski MJ, Sloas MM, Follmann DA, Scalise PP 3rd, Tucker EE, Egan D, and Pizzo PA (1995). Effect of zidovudine and didanosine treatment on heart function in children infected with human immunodeficiency virus (See comments). J Pediatr 127:137-146.

Dubinsky RM, Yarchoan R, Dalakas M, and Broder S (1989). Reversible axonal neuropathy from the treatment of AIDS and related disorders with 2',3'-dideoxycytidine (ddC). Muscle Nerve 12:856-860.

Elimadi A, Morin D, Albengres E, Chauvet-Monges AM, Allain V, Crevat A, and Tillement JP (1997). Differential effects of zidovudine and zidovudine triphosphate on mitochondrial permeability transition and oxidative phosphorylation. $\mathrm{Br} \mathrm{J}$ Pharmacol 121:1295-1300. 
Eriksson S, Xu B, and Clayton DA (1995). Efficient incorporation of anti-HIV deoxynucleotides by recombinant yeast mitochondrial DNA polymerase. J Biol Chem 270:1892918934.

Feldman D and Anderson TD (1994). Schwann cell mitochondrial alterations in peripheral nerves of rabbits treated with 2',3'-dideoxycytidine. Acta Neuropathol 87:71-80.

Feldman D, Brosnan C, and Anderson TD (1992). Ultrastructure of peripheral neuropathy induced in rabbits by $2^{\prime}, 3^{\prime}-$ dideoxycytidine. Lab Invest 66:75-85.

Fleming JE, Miquel J, Cottrell SF, Yengoyan LS, and Economos AC (1982). Is cell aging caused by respirationdependent injury to the mitochondrial genome? Gerontology 28:44-53.

Flint DH, Tuminello JF, and Emptage MH (1993). The inactivation of Fe-S cluster containing hydro-lyases by superoxide. J Biol Chem 268:22369-22376.

Fourel I, Hantz O, Watanabe KA, Jacquet C, Chomel B, Fox JJ, and Trepo C (1990). Inhibitory effects of 2'-fluorinated arabinosyl-pyrimidine nucleosides on woodchuck hepatitis virus replication in chronically infected woodchucks. Antimicrob Agents Chemother 34:473-475.

Freeman BA and Crapo JD (1981). Hyperoxia increases oxygen radical production in rat lungs and lung mitochondria. J Biol Chem 256:10986-10992.

Freese EB, Gerson J, Taber H, Rhaese HJ, and Freese E (1967). Inactivating DNA alterations induced by peroxides and peroxide-producing agents. Mutat Res 4:517-531.

Freiman JP, Helfert KE, Hamrell MR, and Stein DS (1993). Hepatomegaly with severe steatosis in HIV-seropositive patients. Aids 7:379-385.

Gerschenson M, Erhart SW, Paik CY, St Claire MC, Nagashima K, Skopets B, Harbaugh SW, Harbaugh JW, Quan W, and Poirier MC (2000). Fetal mitochondrial heart and skeletal muscle damage in Erythrocebus patas monkeys exposed in utero to $3^{\prime}$-azido-3'-deoxythymidine. AIDS Res Hum Retroviruses 16:635-644.

Gray $\mathrm{H}$ and Wong TW (1992). Purification and identification of subunit structure of the human mitochondrial DNA polymerase. J Biol Chem 267:5835-5841.

Gray NM, Marr CL, Penn CR, Cameron JM, and Bethell RC (1995). The intracellular phosphorylation of (-)-2'-deoxy-3'thiacytidine (3TC) and the incorporation of 3TC $5^{\prime}$ monophosphate into DNA by HIV-1 reverse transcriptase and human DNA polymerase gamma. Biochem Pharmacol 50: 1043-1051.

Groopman JE (1990). Zidovudine intolerance. Rev Infect Dis 12(Suppl 5), S500-506.

Halliwell B and Gutteridge JM (1985). The importance of free radicals and catalytic metal ions in human diseases. Mol Aspects Med 8:89-193.

Harrison DG (1997). Cellular and molecular mechanisms of endothelial cell dysfunction. J Clin Invest 100:2153-2157.

Hart GJ, Orr DC, Penn CR, Figueiredo HT, Gray NM, Boehme RE, Cameron JM (1992). Effects of (-)-2'-deoxy-3'thiacytidine (3TC) 5'-triphosphate on human immunodeficiency virus reverse transcriptase and mammalian DNA polymerases alpha, beta, and gamma. Antimicrob Agents Chemother 36:1688-1694.
Hattori K, Tanaka M, Sugiyama S, Obayashi T, Ito T, Satake T, Hanaki Y, Asai J, Nagano M, and Ozawa T (1991). Age-dependent increase in deleted mitochondrial DNA in the human heart: Possible contributory factor to presbycardia. Am Heart J 121:1735-1742.

Havlir D, Gilbert P, Bennett K, Collier M, Hirsch P, Tebas P, Adams E, Goodwin D, Schnittman S, Holohan MK, and Richman D (2000). Randomized trial of continued Indinavir (IDV)/ZDV/3TC vs switch to IDV/ddl/d4T or IDV/ddl/d4T + hydroxyurea in patients with viral suppression. Paper presented at 7th Conference on Retroviruses and Opportunistic Infections. San Francisco, CA, January 30-February 2, 2000.

Hayakawa M, Hattori K, Sugiyama S, and Ozawa T (1992). Age-associated oxygen damage and mutations in mitochondrial DNA in human hearts. Biochem Biophys Res Commun 189:979-985

Herskowitz A, Willoughby SB, Baughman KL, Schulman SP, and Bartlett JD (1992). Cardiomyopathy associated with antiretroviral therapy in patients with HIV infection: A report of six cases. Ann Intern Med 116:311-313.

Herzberg NH, Zorn I, Zwart R, Portegies P, and Bolhuis PA (1992). Major growth reduction and minor decrease in mitochondrial enzyme activity in cultured human muscle cells after exposure to zidovudine. Muscle Nerve 15:706-710.

Hobbs GA, Keilbaugh SA, Rief PM, and Simpson MV (1995). Cellular targets of 3'-azido-3'-deoxythymidine: An early (nondelayed) effect on oxidative phosphorylation. Biochem Pharmacol 50:381-390.

Hobbs GA, Keilbaugh SA, and Simpson MV (1992). The Friend murine erythroleukemia cell, a model system for studying the association between bone marrow toxicity induced by 3'-azido-3'-dideoxythymidine and dideoxynucleoside inhibition of mtDNA replication. Biochem Pharmacol 43:1397-1400.

Insdorf NF and Bogenhagen DF (1989). DNA polymerase gamma from Xenopus laevis. I. The identification of a high molecular weight catalytic subunit by a novel DNA polymerase photolabeling procedure. J Biol Chem 264:2149121497.

Izuta S, Saneyoshi M, Sakurai T, Suzuki M, Kojima K, and Yoshida S (1991). The 5'-triphosphates of 3'-azido-3'deoxythymidine and 2', 3'-dideoxynucleosides inhibit DNA polymerase gamma by different mechanisms. Biochem Biophys Res Commun 179:776-783.

Jay C and Dalakas MC (1994). Myopathies and neuropathies in HIV-infected adults and children. In: Pizzo $P$ and Wilfert CM, editors. Pediatric AIDS: The challenge of HIV infection in infants, children, and adolescents, 2nd ed. Baltimore: Williams and Wilkins, 559-573.

Jolliet P and Widmann JJ (1990). Reye's syndrome in adult with AIDS (Letter). Lancet 335:1457.

Kaguni LS, Wernette CM, Conway MC, and Yang-Cashman P (1988). Structural and catalytic features of the mitochondrial DNA polymerase from Drosophila melanogaster embryos. In: Kelly $\mathrm{T}$ and Stillman B, editors. Eukaryotic DNA replication. Cold Spring Harbor, NY: Cold Spring Harbor Laboratories, 425-432.

Kakuda TN (2000). Pharmacology of nucleoside and nucleotide reverse transcriptase inhibitor-induced mitochondrial toxicity. Clin Ther 22:685-708. 
Kakuda TN, Brundage RC, Anderson PL, and Fletcher CV (1999). Nucleoside reverse transcriptase inhibitor-induced mitochondrial toxicity as an etiology for lipodystrophy (Letter). AIDS 13:2311-2312.

Katz AM (1998). Is the failing heart energy depleted? Cardiol Clin 16:633-644, viii.

Keilbaugh SA, Hobbs GA, and Simpson MV (1993). Antihuman immunodeficiency virus type 1 therapy and peripheral neuropathy: prevention of 2',3'-dideoxycytidine toxicity in PC12 cells, a neuronal model, by uridine and pyruvate. Mol Pharmacol 44:702-706.

Klecker RW, Katki AG, and Collins JM (1994). Toxicity, metabolism, DNA incorporation with lack of repair, and lactate production for 1-(2'-fluoro-2'-deoxy-beta-Darabinofuranosyl)-5-iodouracil in U-937 and MOLT-4 cells. Mol Pharmacol 46:1204-1209.

Konig H, Behr E, Lower J, and Kurth R (1989). Azidothymidine triphosphate is an inhibitor of both human immunodeficiency virus type 1 reverse transcriptase and DNA polymerase gamma. Antimicrob Agents Chemother 33:2109-2114.

Kuchino Y, Mori F, Kasai H, Inoue H, Iwai S, Miura K, Ohtsuka E, and Nishimura S (1987). Misreading of DNA templates containing 8-hydroxydeoxyguanosine at the modified base and at adjacent residues. Nature 327:77-79.

Kunkel TA and Mosbaugh DW (1989). Exonucleolytic proofreading by a mammalian DNA polymerase. Biochemistry 28:988-995.

Kunkel TA and Soni A (1988). Exonucleolytic proofreading enhances the fidelity of DNA synthesis by chick embryo DNA polymerase-gamma. J Biol Chem 263:4450-4459.

Lambert JS, Seidlin M, Reichman RC, Plank CS, Laverty M, Morse GD, Knupp C, McLaren C, Pettinelli C, and Valentine FT (1990). 2',3'-dideoxyinosine (ddl) in patients with the acquired immunodeficiency syndrome or AIDS-related complex. A phase I trial (See comments). N Engl J Med 322:13331340.

Lamperth L, Dalakas MC, Dagani F, Anderson J, and Ferrari $\mathrm{R}$ (1991). Abnormal skeletal and cardiac muscle mitochondria induced by zidovudine (AZT) in human muscle in vitro and in an animal model. Lab Invest 65:742-751.

Lange $\mathrm{J}$ (1995). Combination antiretroviral therapy. Back to the future. Drugs 49:32-37; Discussion 38-40.

Levine ES and Lewis W (1995). The thymidine analogs fialuridine and zidovidine inhibit mitochondrial energy metabolism in cultured hepatoblasts (Abstract). FASEB J 9:A1398.

Lewis W (1998). Pathologic changes in the hearts of patients with AIDS. In: Lipshultz SE, editor. Cardiology in AIDS. New York: Chapman and Hall, 233-254.

Lewis W and Dalakas MC (1995). Mitochondrial toxicity of antiviral drugs. Nat Med 1:417-422.

Lewis W, Gonzalez B, Chomyn A, and Papoian T (1992). Zidovudine induces molecular, biochemical, and ultrastructural changes in rat skeletal muscle mitochondria. J Clin Invest 89:1354-1360.

Lewis W, Griniuviene B, Tankersley KO, Levine ES, Montione R, Engelman L, de Courten-Myers G, Ascenzi MA, Hornbuckle WE, Gerin JL, and Tennant BC (1997). Depletion of mitochondrial DNA, destruction of mitochondria, and accumulation of lipid droplets result from fialuridine treatment in woodchucks (Marmota monax). Lab Invest 76:77-87.
Lewis W, Grupp IL, Grupp G, Hoit B, Morris R, Samarel AM, Bruggeman L, and Klotman P (2000). Cardiac dysfunction occurs in the HIV-1 transgenic mouse treated with zidovudine. Lab Invest 80:187-197.

Lewis W, Levine ES, Griniuviene B, Tankersley KO, Colacino JM, Sommadossi JP, Watanabe KA, and Perrino FW (1996). Fialuridine and its metabolites inhibit DNA polymerase gamma at sites of multiple adjacent analog incorporation, decrease mtDNA abundance, and cause mitochondrial structural defects in cultured hepatoblasts. Proc Natl Acad Sci USA 93:3592-3597.

Lewis W, Meyer RR, Simpson JF, Colacino JM, and Perrino FW (1994a). Mammalian DNA polymerases alpha, beta, gamma, delta, and epsilon incorporate fialuridine (FIAU) monophosphate into DNA and are inhibited competitively by FIAU Triphosphate. Biochemistry 33:14620-14624.

Lewis W, Papoian T, Gonzalez B, Louie H, Kelly DP, Payne RM, and Grody WW (1991). Mitochondrial ultrastructural and molecular changes induced by zidovudine in rat hearts. Lab Invest 65:228-236.

Lewis W, Simpson JF, and Meyer RR (1994b). Cardiac mitochondrial DNA polymerase-gamma is inhibited competitively and noncompetitively by phosphorylated zidovudine. Circ Res 74:344-348.

Lewis W and Tankersley KO (1995). Triphosphorylated fialuridine and metabolites inhibit cardiac mitochondrial DNA polymerase gamma (DNA polymerase-gamma): Alternative substrates for thymidine triphosphate (dTTP) (Abstract). Circulation 92:I-186.

Lim SE and Copeland WC (In press, 2001). Differential incorporation and removal of anti-viral deoxynucleotides by human DNA polymerase. J Biol Chem.

Lim SE, Longley MJ, and Copeland WC (1999). The mitochondrial p55 accessory subunit of human DNA polymerase gamma enhances DNA binding, promotes processive DNA synthesis, and confers $\mathrm{N}$-ethylmaleimide resistance. J Biol Chem 274:38197-38203.

Linnane AW, Marzuki S, Ozawa T, and Tanaka M (1989). Mitochondrial DNA mutations as an important contributor to aging and degenerative diseases. Lancet 1:642-645.

Linnane AW, Zhang C, Baumer A, and Nagley P (1992). Mitochondrial DNA mutation and the aging process: Bioenergy and pharmacological intervention. Mutat Res 275:195208.

Lipshultz SE, Easley KA, Orav EJ, Kaplan S, Starc TJ, Bricker JT, Lai WW, Moodie DS, Sopko G, Mclntosh K, and Colan SD (2000). Absence of cardiac toxicity of zidovudine in infants. Pediatric Pulmonary and Cardiac Complications of Vertically Transmitted HIV Infection Study Group (See comments). N Engl J Med 343:759-766.

Lipshultz SE, Orav EJ, Sanders SP, Hale AR, McIntosh K, and Colan SD (1992). Cardiac structure and function in children with human immunodeficiency virus infection treated with zidovudine (See comments). N Engl J Med 327:1260-1265.

Lonergan JT, Havlir D, Behling C, Pfander H, Hassanein T, and Mathews WC (2000). Hyperlactatemia in 20 patients receiving NRTI combination regimens. Paper presented at 7th Conference on Retroviruses and Opportunistic Infections. San Francisco, CA, January 30-February 2, 2000.

Longley MJ and Mosbaugh DW (1991). Properties of the $3^{\prime}$ to 5 ' exonuclease associated with porcine liver DNA polymer- 
ase gamma. Substrate specificity, product analysis, inhibition, and kinetics of terminal excision. J Biol Chem 266: 24702-24711.

Macilwain C (1994). US agencies split over inquiry into effects of radiation experiments (News). Nature 368:781.

Marinho HS, Antunes F, and Pinto RE (1997). Role of glutathione peroxidase and phospholipid hydroperoxide glutathione peroxidase in the reduction of lysophospholipid hydroperoxides. Free Radic Biol Med 22:871-883.

Marshall E (1994). Hepatitis study. Drug trial deaths deemed unavoidable (News). Science 264:1530.

Martin JL, Brown CE, Matthews-Davis N, and Reardon JE (1994). Effects of antiviral nucleoside analogs on human DNA polymerases and mitochondrial DNA synthesis. Antimicrob Agents Chemother 38:2743-2749.

Medina DJ, Tsai CH, Hsiung GD, and Cheng YC (1994). Comparison of mitochondrial morphology, mitochondrial DNA content, and cell viability in cultured cells treated with three anti-human immunodeficiency virus dideoxynucleosides. Antimicrob Agents Chemother 38:1824-1828.

Merigan TC, Skowron G, Bozzette SA, Richman D, Uttamchandani R, Fischl M, Schooley R, Hirsch M, Soo W, and Pettinelli C (1989). Circulating p24 antigen levels and responses to dideoxycytidine in human immunodeficiency virus (HIV) infections. A phase I and II study. Ann Intern Med 110:189-194.

Meyer RR and Lewis W (1993). Dideoxynucleoside triphosphates inhibit mitochondrial DNA polymerase- $\gamma$ : Comparison of zidovudine and didanosine (Abstract). J Cell Biochem 17E:18.

Miquel J (1992). An update on the mitochondrial-DNA mutation hypothesis of cell aging. Mutat Res 275:209-216.

Modica-Napolitano JS (1993). AZT causes tissue-specific inhibition of mitochondrial bioenergetic function. Biochem Biophys Res Commun 194:170-177.

Moore R, Keruly J, and Chaisson R (2000a). Differences in anion gap with different nucleoside RTI combinations. Paper presented at 7th Conference on Retroviruses and Opportunistic Infections. San Francisco, CA, January 30-February 2, 2000.

Moore RD, Wong WM, Keruly JC, and McArthur JC (2000b). Incidence of neuropathy in HIV-infected patients on monotherapy versus those on combination therapy with didanosine, stavudine and hydroxyurea. AIDS 14:273-278.

Moraes CT, Shanske S, Tritschler HJ, Aprille JR, Andreetta F, Bonilla E, Schon EA, and DiMauro S (1991). mtDNA depletion with variable tissue expression: A novel genetic abnormality in mitochondrial diseases. Am J Hum Genet 48:492-501.

Moyle G (2000). Clinical manifestations and management of antiretroviral nucleoside analog-related mitochondrial toxicity. Clin Ther 22:911-936; Discussion 898.

Muller-Hocker J (1989). Cytochrome-c-oxidase deficient cardiomyocytes in the human heart: An age-related phenomenon. A histochemical ultracytochemical study. Am J Pathol 134:1167-1173.

Nohl H, Jordan W, and Hegner D (1982). Mitochondrial formation of $\mathrm{OH}$ Radicals by an ubisemiquinone-dependent reaction an alternative pathway to the iron-catalysed HaberWeiss cycle. Hoppe Seylers Z Physiol Chem 363:599-607.
Nusbaum NJ and Joseph PE (1996). AZT incorporation into mitochondria: Study in a human myeloid cell line. DNA Cell Biol 15:363-366.

Parker WB and Cheng YC (1994). Mitochondrial toxicity of NRTI analogs. J NIH Res 6:57-61.

Parker WB, White EL, Shaddix SC, Ross LJ, Buckheit RW Jr, Germany JM, Secrist JAd, Vince R, and Shannon WM (1991). Mechanism of inhibition of human immunodeficiency virus type 1 reverse transcriptase and human DNA polymerases alpha, beta, and gamma by the 5 '-triphosphates of carbovir, 3'-azido-3'-deoxythymidine, 2',3'-dideoxyguanosine and 3'deoxythymidine. A novel RNA template for the evaluation of antiretroviral drugs. J Biol Chem 266:1754-1762.

Pavlov YI, Minnick DT, Izuta S, and Kunkel TA (1994). DNA replication fidelity with 8-oxodeoxyguanosine triphosphate. Biochemistry 33:4695-4701.

Pereira LF, Oliveira MB, and Carnieri EG (1998). Mitochondrial sensitivity to AZT. Cell Biochem Funct 16:173-181.

Peters BS, Winer J, Landon DN, Stotter A, and Pinching AJ (1993). Mitochondrial myopathy associated with chronic zidovudine therapy in AIDS. Q J Med 86:5-15.

Pezeshkpour G, Illa I, and Dalakas MC (1991). Ultrastructural characteristics and DNA immunocytochemistry in human immunodeficiency virus and zidovudine-associated myopathies. Hum Pathol 22:1281-1288.

Pinz KG and Bogenhagen DF (1998). Efficient repair of abasic sites in DNA by mitochondrial enzymes. Mol Cell Biol 18: 1257-1265.

Radi R, Beckman JS, Bush KM, and Freeman BA (1991). Peroxynitrite-induced membrane lipid peroxidation: The cytotoxic potential of superoxide and nitric oxide. Arch Biochem Biophys 288:481-487.

Reyes MG, Casanova J, and Varricchio F (1991). Zidovudine mitochondriopathy of hamster quadriceps muscle (Abstract). Lab Invest 64:89A.

Richardson FC, Engelhardt JA, and Bowsher RR (1994). Fialuridine accumulates in DNA of dogs, monkeys, and rats following long-term oral administration. Proc Natl Acad Sci USA 91:12003-12007.

Richter C (1988). Do mitochondrial DNA fragments promote cancer and aging? (See comments.) FEBS Lett 241:1-5.

Richter C, Park JW, and Ames BN (1988). Normal oxidative damage to mitochondrial and nuclear DNA is extensive. Proc Natl Acad Sci USA 85:6465-6467.

Saint-Marc T, Partisani M, Poizot-Martin I, Bruno F, Rouviere O, Lang JM, Gastaut JA, and Touraine JL (1999). A syndrome of peripheral fat wasting (lipodystrophy) in patients receiving long-term nucleoside analogue therapy. AIDS 13:16591667.

Schapira AH and Cooper JM (1992). Mitochondrial function in neurodegeneration and ageing. Mutat Res 275:133-143.

Schroder JM, Kaldenbach T, and Piroth W (1996). Nuclear and mitochondrial changes of co-cultivated spinal cord, spinal ganglia and muscle fibers following treatment with various doses of zidovudine. Acta Neuropathol (Berl) 92:138-149.

Semino-Mora MC, Leon-Monzon ME, and Dalakas MC (1994). The effect of L-carnitine on the AZT-induced destruction of human myotubes. Part II: Treatment with L-carnitine improves the AZT-induced changes and prevents further destruction. Lab Invest 71:773-781. 
Shoubridge EA (1994). Mitochondrial DNA diseases: Histological and cellular studies. J Bioenerg Biomembr 26:301310.

Simpson MV, Chin CD, Keilbaugh SA, Lin TS, and Prusoff WH (1989). Studies on the inhibition of mitochondrial DNA replication by $3^{\prime}$-azido-3'-deoxythymidine and other dideoxynucleoside analogs which inhibit HIV-1 replication. Biochem Pharmacol 38:1033-1036.

Sinnwell TM, Sivakumar K, Soueidan S, Jay C, Frank JA, McLaughlin AC, and Dalakas MC (1995). Metabolic abnormalities in skeletal muscle of patients receiving zidovudine therapy observed by $31 \mathrm{P}$ in vivo magnetic resonance spectroscopy. J Clin Invest 96:126-131.

Spencer JP, Wong J, Jenner A, Aruoma OI, Cross CE, and Halliwell B (1996). Base modification and strand breakage in isolated calf thymus DNA and in DNA from human skin epidermal keratinocytes exposed to peroxynitrite or 3-morpholinosydnonimine. Chem Res Toxicol 9:1152-1158.

Stevenson W, Gaffey M, Ishitani M, McCullough C, Dickson R, Caldwell S, Lobo P, and Pruett T (1995). Clinical course of four patients receiving the experimental antiviral agent fialuridine for the treatment of chronic hepatitis $\mathrm{B}$ infection. Transplant Proc 27:1219-1221.

Sutliff RL, Paul RJ, and Lewis W (2000). Aortas from NL4-3 gag/pol AIDS mice have impaired endothelium-dependent relaxation. Paper presented at FASEB: Experimental Biology 2000, San Diego, CA, April 15-18, 2000.

Swartz MN (1995). Mitochondrial toxicity: New adverse drug effects (Editorial; Comment). N Engl J Med 333:1099-1105.

Szabados E, Fischer GM, Toth K, Csete B, Nemeti B, Trombitas K, Habon T, Endrei D, Sumegi B (1999). Role of reactive oxygen species and poly-ADP-ribose polymerase in the development of AZT-induced cardiomyopathy in rat. Free Radic Biol Med 26:309-17.

Szabo C, Day BJ, and Salzman AL (1996). Evaluation of the relative contribution of nitric oxide and peroxynitrite to the suppression of mitochondrial respiration in immunostimulated macrophages using a manganese mesoporphyrin superoxide dismutase mimetic and peroxynitrite scavenger. FEBS Lett 381:82-86.

Tangeras A, Flatmark T, Backstrom D, and Ehrenberg A (1980). Mitochondrial iron not bound in heme and iron-sulfur centers. Estimation, compartmentation and redox state. Biochim Biophys Acta 589:162-175.

Taylor DE, Ghio AJ, and Piantadosi CA (1995). Reactive oxygen species produced by liver mitochondria of rats in sepsis. Arch Biochem Biophys 316:70-76.

Tennant BC, Baldwin BH, Graham LA, Ascenzi MA, Hornbuckle WE, Rowland PH, Tochkov IA, Yeager AE, Erb HN, Colacino JM, Lopez C, Engelhardt JA, Bowsher RR, Richardson FC, Lewis W, Cote PJ, Korba BE, and Gerin JL (1998). Antiviral activity and toxicity of fialuridine in the woodchuck model of hepatitis B virus infection. Hepatology 28:179-191.
Ter Hofstede H, De Marie S, Foudraine N, Danner S, and Brinkman K (2000). Four cases of fatal lactic acidosis due to mitochondrial toxicity of NRTI treatment: Analysis of clinical features and risk factors. Paper presented at 7 th Conference on Retroviruses and Opportunistic Infections, San Francisco, $\mathrm{CA}$,

Till M and MacDonell KB (1990). Myopathy with human immunodeficiency virus type 1 (HIV-1) infection: HIV-1 or zidovudine? Ann Intern Med 113:492-494.

Tsai CH, Doong SL, Johns DG, Driscoll JS, and Cheng YC (1994). Effect of anti-HIV 2'-beta-fluoro-2',3'-dideoxynucleoside analogs on the cellular content of mitochondrial DNA and on lactate production. Biochem Pharmacol 48:1477-1481.

Turrens JF, Freeman BA, and Crapo JD (1982). Hyperoxia increases $\mathrm{H}_{2} \mathrm{O}_{2}$ release by lung mitochondria and microsomes. Arch Biochem Biophys 217:411-421.

Wallace DC (1992a). Diseases of the mitochondrial DNA. Annu Rev Biochem 61:1175-1212.

Wallace DC (1992b). Mitochondrial genetics: A paradigm for aging and degenerative diseases? Science 256:628-632.

Wang $\mathrm{H}$, Lemire BD, Cass CE, Weiner JH, Michalak M, Penn $A M$, and Fliegel L (1996). Zidovudine and dideoxynucleosides deplete wild-type mitochondrial DNA levels and increase deleted mitochondrial DNA levels in cultured Kearns-Sayre syndrome fibroblasts. Biochim Biophys Acta 1316:51-59.

Wang Y, Farr CL, and Kaguni LS (1997). Accessory subunit of mitochondrial DNA polymerase from Drosophila embryos. Cloning, molecular analysis, and association in the native enzyme. J Biol Chem 272:13640-13646.

Wernette CM and Kaguni LS (1986). A mitochondrial DNA polymerase from embryos of Drosophila melanogaster. Purification, subunit structure, and partial characterization. J Biol Chem 261:14764-14770.

White EL, Parker WB, Macy LJ, Shaddix SC, McCaleb G, Secrist JA, Vince R, and Shannon WM (1989). Comparison of the effect of Carbovir, AZT, and dideoxynucleoside triphosphates on the activity of human immunodeficiency virus reverse transcriptase and selected human polymerases. Biochem Biophys Res Commun 161:393-398.

Wright GE and Brown NC (1990). Deoxyribonucleotide analogs as inhibitors and substrates of DNA polymerases. Pharmacol Ther 47:447-497.

Yakes FM and Van Houten B (1997). Mitochondrial DNA damage is more extensive and persists longer than nuclear DNA damage in human cells following oxidative stress. Proc Natl Acad Sci USA 94:514-519.

Yarchoan R, Pluda JM, Thomas RV, Mitsuya H, Brouwers P, Wyvill KM, Hartman N, Johns DG, and Broder S (1990). Long-term toxicity/activity profile of $2^{\prime}, 3^{\prime}$-dideoxyinosine in AIDS or AIDS-related complex (See comments). Lancet 336: 526-529. 